\title{
Practice of Horticultural Activities Training Program for the Staff in the Nursing Home
}

\author{
Junko Masuya $^{1}$, Kikuko Ota ${ }^{2}$ and Yuriko Mashida ${ }^{2}$ \\ ${ }^{1}$ Faculty of Health Sciences, Tokyo Metropolitan University, 7-2-10, Higashiogu, Arakawa-ku, Tokyo 116-8551, Japan \\ ${ }^{2}$ Faculty of Nursing and Medical Care, Keio University, 4411, Endo, Fujisawa-shi, Kanagawa 252-082, Japan
}

\section{Abstract}

Objective: The purpose of this study was to examine the effects of an intervention of a horticultural activities training program for the staff in the nursing home.

Methods: The participants ( $\mathrm{n}=13$ ) were the staff in the nursing home (nurses, care workers, occupational therapists). They were divided into six to seven people per group (a total of 2 groups). The training was carried out 90 min once a month. The training was carried out a practice and lecture. It was carried out a total of four times for each group. We conducted a questionnaire on training content after the training. Results: From the answers of the participants to the training content, participants showed almost satisfaction to the training content. Our results demonstrate the benefits of participation in a horticultural activities training program improved after the intervention. With regard to comments, Training content would lead to acquisition of knowledge about horticultural activities, and an increased motivation to care for dementia using of horticultural activities.

Conclusions: We suggest that horticultural activities training program would lead to interest in horticultural activities for dementia to staffs, and increased motivation for the use of horticultural activities to staffs. However, the number of participants in this study was small. Therefore, further, involving a greater number of participants are necessary to confirm the effects of horticultural activities training program for the staff in the nursing home.

\section{Introduction}

Now the number of people with dementia is rapidly increasing with the increase of the number of elderly people. The number of people around the world living with dementia is predicted to rise to 135 million by 2050 [1]. Aging in Japan is advancing at a globally unprecedented rate, and there is a need to provide high quality nursing care for aged people. Treatment and effective prevention methods of Alzheimer's disease has not yet been discovered. Thus, in health-care settings such as nursing homes and day care centers, "nonpharmacologic" approaches are being introduced to help maintain the mental condition of elderly people with dementia [2]. Nonpharmacologic therapies include music, reminiscence, art, and reality orientation therapies, and have been shown to improve quality of life (QOL) and prevent disability among elderly people. Among these therapies, horticultural activities encourage interaction between people and plants [3]. The usefulness of horticultural activities in the field of dementia is beginning to be recognised by the scientific community. And it have reported psychologic [4], physical [5], social [6], and cognitive [7] benefits.

The authors have tried to develop a horticultural activities program for elderly patients with mild to moderate dementia[8]. And we have tried to examine the effects of an intervention of a horticultural activities program. These results suggested that this program is effective care method in order to improve vitality, cognitive function, and Behavioral and Psychological Symptoms of Dementia (BPSD) [9]. Further studies on the spread of horticultural activities for elderly people with dementia are needed. This time, the authors have developed a horticultural activities training program for the staff in the nursing home facility. The purpose of this study was to examine the effects of an intervention of a horticultural activities training program for the staff in the nursing home.

\section{Publication History:}

Received: November 05, 2016 Accepted: December 12, 2016 Published: December 14, 2016

\section{Keywords:}

Dementia, Horticultural activities Training program, The staff in the nursing home

\section{Methods}

\section{Participants}

The participants $(n=13)$ were the staff in the nursing home. The distribution of participants is shown in Table 1. The participants comprised nurses, care workers, occupational therapists. [2 men and 11 women]. They were divided into six to seven people per group (a total of 2 groups). The researchers explained the study's objectives and methods and that the potential participants had the freedom of choice to participate in the study.

\section{Intervention methods}

The training was carried out 90 min once a month. The training was carried out a practice and lecture. The basic session flow and schedule are shown in Table 2. It was carried out a total of four times for each group. We conducted a questionnaire on training content after the training.

\section{Evaluation methods and statistical analyses}

After completion of the program, we examined participants' learning needs and attitude changes, using five questionnaire:

"Corresponding Author: Munko Masuya, Faculty of Health Sciences, Tokyo Metropolitan University, 7-2-10, Higashiogu, Arakawa-ku, Tokyo 116-8551, Japan, Tel: +81-3-3819-7168, Fax: +81-3-3819-7168; E-mail: masuya@tmu.ac.jp

Citation: Masuya J, Ota K, Mashida Y (2016) Practice of Horticultural Activities Training Program for the Staff in the Nursing Home. Int J Nurs Clin Pract 3: 214. doi: https://doi.org/10.15344/2394-4978/2016/214

Copyright: () 2016 Masuya et al. This is an open-access article distributed under the terms of the Creative Commons Attribution License, which permits unrestricted use, distribution, and reproduction in any medium, provided the original author and source are credited. 
Citation: Masuya J, Ota K, Mashida Y (2016) Practice of Horticultural Activities Training Program for the Staff in the Nursing Home. Int J Nurs Clin Pract 3: 214. doi: https://doi.org/10.15344/2394-4978/2016/214

Page 2 of 3

\begin{tabular}{|c|c|c|}
\hline Department & Response category & $\mathrm{n}(\%)$ \\
\hline \multirow[t]{2}{*}{ Gender } & Female & $11(82 \%)$ \\
\hline & Male & $2(18 \%)$ \\
\hline \multicolumn{3}{|l|}{ Age (year) } \\
\hline & $20-29$ & $4(30.8 \%)$ \\
\hline & $30-39$ & $2(15.4 \%)$ \\
\hline & $40-49$ & $4(30.8 \%)$ \\
\hline & $50-59$ & $2(15.4 \%)$ \\
\hline & $60-69$ & $0(0 \%)$ \\
\hline & $70-79$ & $1(7.7 \%)$ \\
\hline \multirow[t]{3}{*}{ profession } & Nurses & $4(30.8 \%)$ \\
\hline & Occupational therapists & $1(7.7 \%)$ \\
\hline & Care workers & $8(61.5 \%)$ \\
\hline \multirow[t]{5}{*}{ Seniority (year) } & $<3$ & $2(15.4 \%)$ \\
\hline & $3-5$ & $1(7.7 \%)$ \\
\hline & $5-10$ & $3(23.1 \%)$ \\
\hline & $10-15$ & $2(15.4 \%)$ \\
\hline & $>15$ & $5(38.5 \%)$ \\
\hline \multirow[t]{2}{*}{ Gardening experience } & $\begin{array}{l}\text { Very little to some } \\
\text { experience }\end{array}$ & $8(61.5 \%)$ \\
\hline & A lot of experience & $5(38.5 \%)$ \\
\hline
\end{tabular}

\begin{tabular}{|l|l|l|}
\hline \multicolumn{1}{|c|}{ Session } & \multicolumn{1}{|c|}{ Lecture (60min) } & \multicolumn{1}{|c|}{ Practice(30 min) } \\
\hline $\begin{array}{l}\text { The first } \\
\text { time }\end{array}$ & $\begin{array}{l}\text { Overview and method } \\
\text { development of } \\
\text { horticultural activities. }\end{array}$ & Transplant succulent \\
\hline $\begin{array}{l}\text { The second } \\
\text { time }\end{array}$ & $\begin{array}{l}\text { Management method } \\
\text { of horticultural } \\
\text { activities }\end{array}$ & Seeding white sprouts \\
\hline $\begin{array}{l}\text { The third } \\
\text { time }\end{array}$ & $\begin{array}{l}\text { Planning method and } \\
\text { evaluation method of } \\
\text { horticultural activities. }\end{array}$ & $\begin{array}{l}\text { Planning of horticultural } \\
\text { activities. }\end{array}$ \\
\hline $\begin{array}{l}\text { The fourth } \\
\text { time }\end{array}$ & $\begin{array}{l}\text { Practical experience of } \\
\text { horticultural activities }\end{array}$ & $\begin{array}{l}\text { Horticultural activity } \\
\text { practice experience in the } \\
\text { role-playing }\end{array}$ \\
\hline
\end{tabular}

Table 2: Design of the horticultural activities training program.

Q1.Training materials was appropriate; Q2.Training number was appropriate; Q3.Training time was appropriate; Q4.Training content was able to understand ; and Q5.Training content is useful to the future of care. For the responses, we used a five-point Likert scale with possible answers to each question being: (i)Agree very much ; (ii) Agree considerably ; (iii) Cannot say either way ; (iv) Disagree somewhat ; (v) Completely disagree. We carried out a statistical analysis of the quantitative data and categorized the qualitative data.

\section{Results}

Answers of the participants to the training content are shown in Table 3. With regard to questionnaire 1, "Agree very much" and "Agree

\begin{tabular}{|c|c|c|c|c|c|}
\hline \multirow{2}{*}{$\begin{array}{l}\text { Training content Questions } \\
\text { inquiring about }\end{array}$} & \multicolumn{5}{|c|}{ Responses (participant $\mathrm{n}=13$ ) } \\
\hline & Agree very much & Agree considerably & $\begin{array}{l}\text { Cannot say } \\
\text { either way }\end{array}$ & $\begin{array}{l}\text { Disagree } \\
\text { somewhat }\end{array}$ & Completely disagree \\
\hline $\begin{array}{l}\text { Q1.Training materials was } \\
\text { appropriate }\end{array}$ & $2(15.4 \%)$ & $9(69.4 \%)$ & $0(0.0 \%)$ & $2(15.4 \%)$ & $0(0.0 \%)$ \\
\hline $\begin{array}{l}\text { Q2.Training number was } \\
\text { appropriate }\end{array}$ & $7(53.8 \%)$ & $6(46.2 \%)$ & $0(0.0 \%)$ & $0(0.0 \%)$ & $0(0.0 \%)$ \\
\hline $\begin{array}{l}\text { Q3.Training time was } \\
\text { appropriate }\end{array}$ & $6(46.2 \%)$ & $7(53.8 \%)$ & $0(0.0 \%)$ & $0(0.0 \%)$ & $0(0.0 \%)$ \\
\hline $\begin{array}{l}\text { Q4.Training content was able to } \\
\text { understand }\end{array}$ & $7(53.8 \%)$ & $6(46.2 \%)$ & $0(0.0 \%)$ & $0(0.0 \%)$ & $0(0.0 \%)$ \\
\hline $\begin{array}{l}\text { Q5.Training content is useful to } \\
\text { the future of care }\end{array}$ & $10(76.9 \%)$ & $3(23.1 \%)$ & $0(0.0 \%)$ & $0(0.0 \%)$ & $0(0.0 \%)$ \\
\hline $\begin{array}{l}\text { Q6. Please add any comments in } \\
\text { below form }\end{array}$ & Commemts & \multicolumn{4}{|c|}{$\begin{array}{l}\text { This program is, overlapping each training, it seems to be interest had became } \\
\text { increasing. }\end{array}$} \\
\hline & & \multicolumn{4}{|c|}{$\begin{array}{l}\text { I was glad to be able to learn about culture way of plants and teaching way for people } \\
\text { with dementia. }\end{array}$} \\
\hline & & \multicolumn{4}{|c|}{ The training, there is a lecture and practice, I were able to learn happily. } \\
\hline & & \multicolumn{4}{|c|}{ Anytime soon, I felt that want to go horticultural activities. } \\
\hline & & \multicolumn{4}{|c|}{ Understanding of horticultural activities were deepened. } \\
\hline & & \multicolumn{4}{|c|}{$\begin{array}{l}\text { In the future, while evaluating the change of the residents, we want to go gardening } \\
\text { activities. }\end{array}$} \\
\hline & & \multicolumn{4}{|c|}{$\begin{array}{l}\text { In the future, we want to go gardening activities while evaluating the change of the } \\
\text { nursing home residents. }\end{array}$} \\
\hline & & \multicolumn{4}{|c|}{ The contents of the training is easy to understand, I could use immediately. } \\
\hline
\end{tabular}

Table 3: Answers of the participants to the training content. 
considerably" had high values of more than $80.0 \%$. For questionnaire $2,3,4$, and 5, results for the values of participants who selected "Agree very much" and "Agree considerably" were $100.0 \%$. With regard to comments, Training content would lead to acquisition of knowledge about horticultural activities, and an increased motivation to care for dementia using of horticultural activities.

\section{Discussion}

To increase the effectiveness and extent of horticultural activities program in dementia care settings, it is important to interact in a manner that alters the staff members' awareness and thereby behavior This will enable staff members and participants to experience horticultural activities together, and staff members themselves would become interested in horticultural activities and thereby would identify a corresponding change in participants [9].

In this study, the authors have developed a horticultural activities training program for the staff in the nursing home. Then, we examined the effect of intervention of the program. From the answers of the participants to the training content, participants showed almost satisfaction to the training content.

Our results demonstrate the benefits of participation in a horticultural activities training program improved after the intervention. We suggest that horticultural activities training program would lead to interest in horticultural activities for dementia to staffs, and increased motivation for the use of horticultural activities to staffs. The major limitations of this study were the small number of participants. Therefore, further, involving a greater number of participants are necessary to confirm the effects of horticultural activities training program for the staff in the nursing home.

\section{Limitations}

The major limitations of this study were the small number of participants. Therefore, further, involving a greater number of participants are necessary to confirm the effects of horticultural activities training program for the staff in the nursing home.

\section{Conclusions}

The purpose of this study was to examine the effects of an intervention of a horticultural activities training program for the staff in the nursing home. We suggest that horticultural activities training program would lead to interest in horticultural activities for dementia to staffs, and increased motivation for the use of horticultural activities to staffs. In the future, it is necessary to confirm the effect of horticultural activities by the staff who received the training.

\section{Competing Interests}

The authors declare that they have no competing interests.

\section{Author Contributions}

All the authors substantially contributed to the study conception and design as well as the acquisition and interpretation of the data and drafting the manuscript.

\section{Acknowledgements}

The authors are grateful to all participants and the care staff of the facility.

\section{Funding}

This study was supported by the Tokyo Metropolitan University Young Researcher Support Grants (in 2015).

\section{References}

1. Arokiasamy $P$, Uttamacharya U, Jain K, Biritwum RB, Yawson AE, et al (2015) The impact of multimorbidity on adult physical and mental health in low- and middle-income countries: what does the study on global ageing and adult health (SAGE) reveal? BMC Med 13: 178.

2. Jimbo D, Kimura Y, Taniguchi M, Inoue M, Urakami K (2009) Effect of aromatherapy on patients with Alzheimer's disease. Psychogeriatrics 9: 173-179.

3. Masuya J, Ota K (2014) Efficacy of horticultural activity in elderly people with dementia: A pilot study of the influence on vitality and cognitive function. Int J Nurs Clin Pract 1: 101

4. Sugihara S, Aoyama H, Sugimoto M, Takeda S, Ikeda N, et al. (2006) The psychological, cognitive and immunological effects of hortcultural therapy on the elderly living in a nursing home. Japanese Journal of Geriatric Psychiatry 17: 967-975.

5. Brown VM, Allen AC, Dwozan M, Mercer I, Warren K, et al. (2004) Indoor gardening and older adults-effect of socialization, activities of daily living, and loneliness. J Gerontol Nurs 30: 34-42.

6. Tse MM (2010) Therapeutic effects of an indoor gardening programme for older people living in nursing homes. J Clin Nurs 19: 949-958.

7. Yamada S, Toba K (2005) A prospective comparison of day care and freely chosen occupational therapy for elderly patients with dementia. Nihon Ronen Igakkai Zasshi 42: 83-89.

8. Masuya J (2011) Development of horticultural activities program to change behavior for the elderly with dementia. Jan J Academy of Gerontological Nursing 15: 54-63.

9. Masuya J, Ota K (2014) Efficacy of horticultural activities program for the elderly people with mild to moderate dementia. Journal of Japanese society of People-Plant Relationships 13: 1-7. 